ISSN (print): 1698-6180. ISSN (online): 1886-7995

www.ucm.es/info/estratig/journal.htm

Journal of Iberian Geology 38 (1) 2012: 285-302

http://dx.doi.org/10.5209/rev_JIGE.2012.v38.n1.39219

\title{
The Quaternary Active Faults Database of Iberia (QAFI v.2.0)
}

\author{
La Base de Datos de Fallas Activas en el Cuaternario de Iberia (QAFI v.2.0)
}

\author{
J. García-Mayordomo $^{1}$ *, J.M. Insua-Arévalo ${ }^{2}$, J.J. Martínez-Díaz ${ }^{2}$, A. Jiménez-Díaz ${ }^{2}$, \\ R. Martín-Banda ${ }^{1}$, S. Martín-Alfageme ${ }^{1}$, J.A. Álvarez-Gómez ${ }^{3}$, M. Rodríguez-Peces ${ }^{2}$, \\ R. Pérez-López ${ }^{1}$, M.A. Rodríguez-Pascua ${ }^{1}$, E. Masana $^{4}$, H. Perea ${ }^{5}$, F. Martín-González ${ }^{6}$, \\ J. Giner-Robles ${ }^{7}$, E.S. Nemser ${ }^{8}$, J. Cabral $^{5}$, and QAFI Compilers** \\ ${ }^{1}$ Instituto Geológico y Minero de España, Madrid, Spain \\ julian.garcia@igme.es,r.martin@igme.es,s.martin@igme.es,r.perez@igme.es,ma.rodriguez@igme.es \\ ${ }^{2}$ Dpt. de Geodinámica, Facultad de Ciencias Geológicas, Universidad Complutense de Madrid, Madrid, Spain. \\ insuarev@geo.ucm.es,jmdiaz@geo.ucm.es,ajimenezdiaz@geo.ucm.es,martinjr@geo.ucm.es \\ ${ }^{3}$ Instituto de Hidráulica Ambiental "IH Cantabria", Universidad de Cantabria, Santander, Spain \\ joseantonio.alvarezgomez@unican.es \\ ${ }^{4}$ Departament de Geodinàmica i Geofísica, Universidad de Barcelona, Barcelona, Spain \\ eulalia.masana@ub.edu, hector.perea@fc.ul.pt \\ ${ }^{5}$ Departamento de Geologia / Instituto D. Luiz, Faculdade de Ciências, Universidade de Lisboa, Portugal \\ jcabral@fc.ul.pt \\ ${ }^{6}$ Área de Geología -ESCET-, Universidad Rey Juan Carlos, Móstoles (Madrid), Spain \\ fidel.martin@urjc.es \\ ${ }^{7}$ Departamento de Geología y Geoquímica. Universidad Autónoma de Madrid, Madrid, Spain \\ jorge.giner@uam.es \\ ${ }^{8}$ Instituto Superior Técnico, Lisboa, Portugal. \\ eliza.nemser@ist.utl.pt \\ **QAFI Compilers: C. Sanz de Galdeano, J.A. Peláez, F.J. García-Tortosa, E. Gràcia, R. Bartolomé, Á. González, \\ J.M. Azañón, P. Alfaro, X. Moreno, A. Ferrero-Vega, R. Dias, S. Martínez, F. Gutiérrez, M. Ortuño, G. Booth-Rea, \\ F. Giaconia, J.M. Martínez-Martínez, I. Villegas, C. Lo Iacono, V. Pérez-Peña, F. Martín-González, A. Brum da \\ Silveira, E. García-Meléndez, P. Lafuente, J.L. Simón, L.E. Arlegui, C.L. Liesa, J. Bach, R. Linares. \\ *corresponding author
}

Received: 24/12/2011 / Accepted: 05/03/2012

Abstract

The Quaternary Active Faults Database of Iberia (QAFI) is an initiative lead by the Institute of Geology and Mines of Spain (IGME) for building a public repository of scientific data regarding faults having documented activity during the last $2.59 \mathrm{Ma}$ (Quaternary). QAFI also addresses a need to transfer geologic knowledge to practitioners of seismic hazard and risk in Iberia by identifying and characterizing seismogenic fault-sources. QAFI is populated by the information freely provided by more than 40 Earth science researchers, storing to date a total of 262 records. In this article we describe the development and evolution of the 
database, as well as its internal architecture. Additionally, a first global analysis of the data is provided with a special focus on length and slip-rate fault parameters. Finally, the database completeness and the internal consistency of the data are discussed. Even though QAFI v.2.0 is the most current resource for calculating fault-related seismic hazard in Iberia, the database is still incomplete and requires further review.

Keywords: Active fault, Quaternary, Iberia, Spain, Portugal, Seismic hazard

\section{Resumen}

La Base de Datos de Fallas Activas de Iberia (QAFI) es una iniciativa promovida por el Instituto Geológico y Minero de España (IGME) para construir un repositorio público de información científica sobre fallas con actividad en los últimos 2,59 Ma (Cuaternario). Además, la QAFI persigue establecer una base sobre la que facilitar la transferencia de conocimiento geológico al ámbito tecnológico de la gestión del riesgo sísmico en Iberia, en particular en la identificación y caracterización de fuentes sismogénicas tipo falla. La QAFI se ha construido a partir de la información proporcionada de modo altruista por más de 40 investigadores en ciencias de la Tierra conteniendo actualmente un total de de 262 registros. En este artículo se describe la concepción y evolución de la base de datos, y su arquitectura interna. Además, se ofrece un primer análisis global de los datos que contiene, con especial interés en parámetros tan importantes como la longitud y tasa de deslizamiento de las fallas. Finalmente se discuten dos temas cruciales en cualquier base de datos: su completitud y la homogeneidad de los datos. Se concluye que QAFI v.2.0, pese a ser la fuente más actualizada de información disponible en Iberia sobre peligrosidad sísmica de fallas concretas, dista aun de ser completa, por lo que nuevas revisiones y versiones deberán seguir llevándose a cabo en el futuro.

Palabras clave: Falla activa, Cuaternario, Iberia, España, Portugal, Peligrosidad sísmica

\section{Introduction}

A major task of national geological surveys worldwide consists in the production of knowledge infrastructure related to geological hazards. Concerning earthquake hazard, the identification and characterization of those faults potentially capable of producing damaging earthquakes is doubtlessly one of the most relevant challenges, both from its scientific interest for earthquake geologists and seismologists, and its practical application in seismic hazard and risk analyses.

The creation of the Quaternary Active Faults Database of Iberia (QAFI) hosted by the Institute of Geology and Mines of Spain (IGME, 2012) joins European and international initiatives aimed at providing to the public domain information on active faults (cf. Trifonov, 2004; Basili et al., 2008; DISS Working Group, 2010; USGS, 2010; AFRC, 2010; GNS, 2010; NEOPAL, 2010; GEMFaulted Earth, 2011). The QAFI project also aims to resume the research and service activities of IGME in seismic hazard matters at a national scale in Spain, as for example the Neotectonic Map of Spain (IGME and ENRESA, 1998); as well as gathering, unifying and boosting individual efforts already produced in the country for different regions (Sanz de Galdeano et al., 2003, 2007; GarcíaMayordomo, 2005; Perea et al., 2006). The database also integrates pertinent information concerning active faults in mainland Portugal and the adjacent Atlantic area, in order to develop a coherent and comprehensive neotectonic framework of the Iberian Peninsula.
The objective of QAFI is twofold: 1) to became the official repository of scientific data on active faults in Iberia and, 2) to facilitate knowledge transfer to the technological fields and administrative needs in seismic hazard issues. To reach the first objective the database concerns only faults with geological and/or seismological evidence of being active during the Quaternary -i.e, the last 2.59 Ma according to the limit recently established by the Subcommission in Quaternary Stratigraphy of INQUA (cf. Gibbard et al., 2009). Even though this cut off is older than those considered in other countries of major seismic activity, it seems appropriate for revealing the Iberian geodynamics. Additionally, because Iberian fault slip rates are slower and seismic cycles are longer than in other more active countries it is prudent to extend the time window of the database to include potentially hazardous seismogenic sources with low rates of occurrence. This is particularly interesting as many faults that were classified as Plio-Quaternary in official Spanish geological cartographies are now properly Quaternary. Considering sources such as these can have an important impact on studies devoted to seismic hazard reassessment, particularly those targeted for long return periods.

A major difference with other fault databases is that QAFI has been populated through free collaborations of many Earth science researchers. This fact has greatly facilitated its creation, although it has also implied an extra effort in ensuring a minimum level of quality and uniformity of the data. Thereby, QAFI v.2.0 demonstrates Iberian geologists' real interest in tendering their knowledge 
STAGES

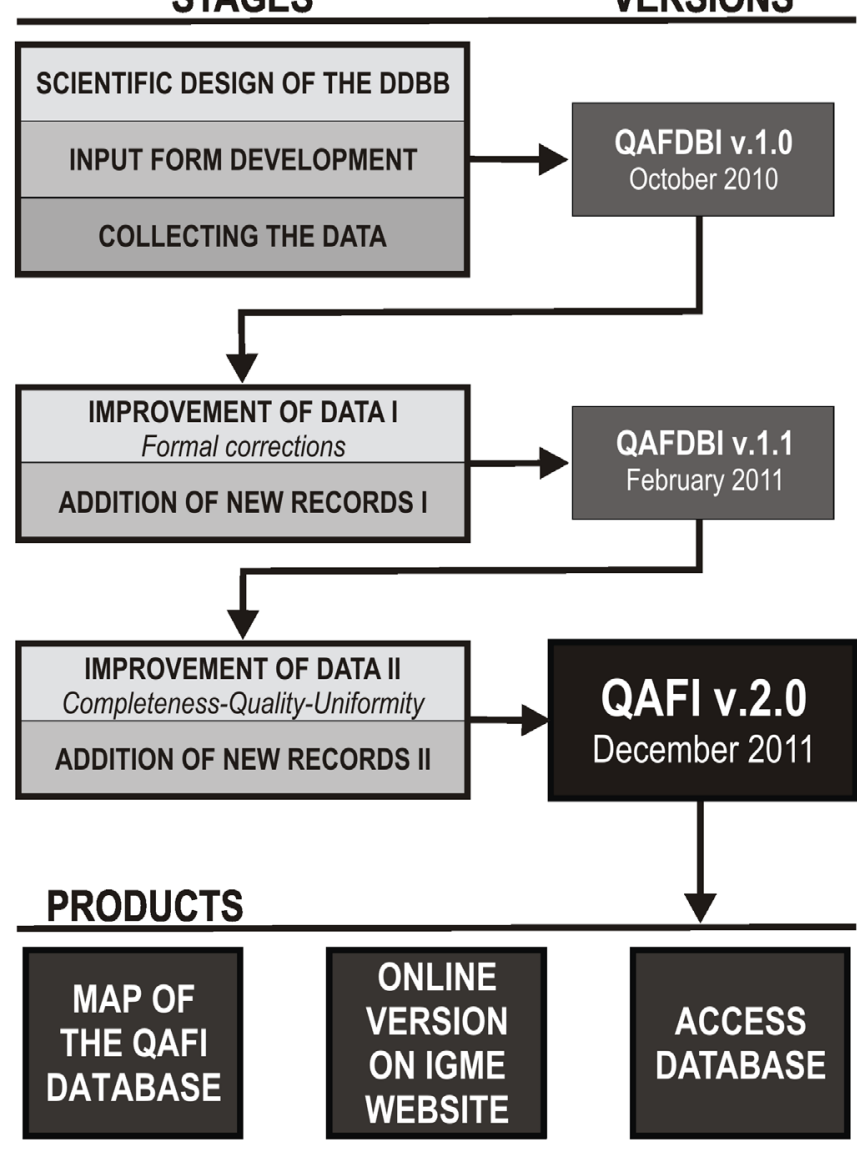

Fig. 1.- Conception, phases and evolution of the QAFI database. Fig. 1.- Concepción, fases y evolución de la base de datos QAFI.

to help society and, likewise, the responsibility of IGME in conveying it in the most effective way.

\section{Conception and evolution of the database}

The creation of the database has followed successive phases that have led to a number of versions prior to the present v.2.0 (Fig. 1). The first phase comprised the scientific design of the database which was agreed among the authors after consulting other existing databases of national and continental scope: the Italian Database of Individual Seismogenic Sources (Basili et al., 2008; DISS Working Group, 2010), New Zealand Active Faults Database (GNS, 2010), Quaternary Faults and Folds Database of the United States (USGS, 2010), Active Faults Database of Japan (AFRC, 2010), and the Database of Potential Sources for Earthquakes Larger than M 5.5 in Europe (Valensise et al., 2002). Fields were defined bearing in mind all the potential uses that the database could have later for scientific use as well as for application in seismic hazard calculations. The Italian DISS database (Basili et al., 2008; DISS Working Group, 2010) was analysed in particular, as it is the basis for the European project SHA$\mathrm{RE}$ and in view of an eventual implementation of QAFI in a European active faults database.

An important difference from DISS and other databases is that QAFI was designed to be populated by the free collaboration of Earth science researchers rather than by a team specifically formed for the task. This required creating a user friendly interface for typical PC users. The form was created in MicroSoft Access ${ }^{\circledR} 2003$ program, which we also use to store, query and even print the records in different ways.

The process of collecting the data was carried out taking advantage of the Iberfault meeting, the First Iberian Meeting on Active Faults and Paleosismology (Iberfault) held in October 2010. At this meeting the first version of the database (called then QAFDBI v.1.0) was presented containing a total of 239 records (García-Mayordomo et al., 2010). After Iberfault, the information provided for each record was reviewed and the compilers were subsequently contacted to correct the detected errors. A few cases of duplicity -i.e., different records corresponding to the same fault but having a different name or interpretation, were found and then resolved after contacting the different compilers involved. In only one case it was decided to keep two different records for the same fault (see section 4). At the same time, the database schema was revised and new fields were created, some records being deleted while other new ones were added. Finally, the revised database containing a total of 223 records was publically released in February 2011 under the name QAFDBI v.1.1.

\subsection{QAFI v.2.0}

The data contained in QAFDBI v.1.1 were thoroughly reviewed in order to improve the quality and uniformity of the information. This process was conducted by reviewing the literature referenced for each record and correcting the content; compilers were contacted to get their permission for the changes. New records were added by the database authorship team to address issues of completeness of the database. It is important to mention that in the previous versions of the database the compilers were also major researchers on the respective faults.

The above mentioned changes and additions have led to the most recent version of the database which has also a new acronym: QAFI. QAFI v.2.0 was completed in December 2011 and includes 262 records. Additionally, in contrast to older versions in which the records were plotted as vector-lines, QAFI v.2.0 includes a map of the actual fault traces (see Annex 1). QAFI v.2.0 is available 


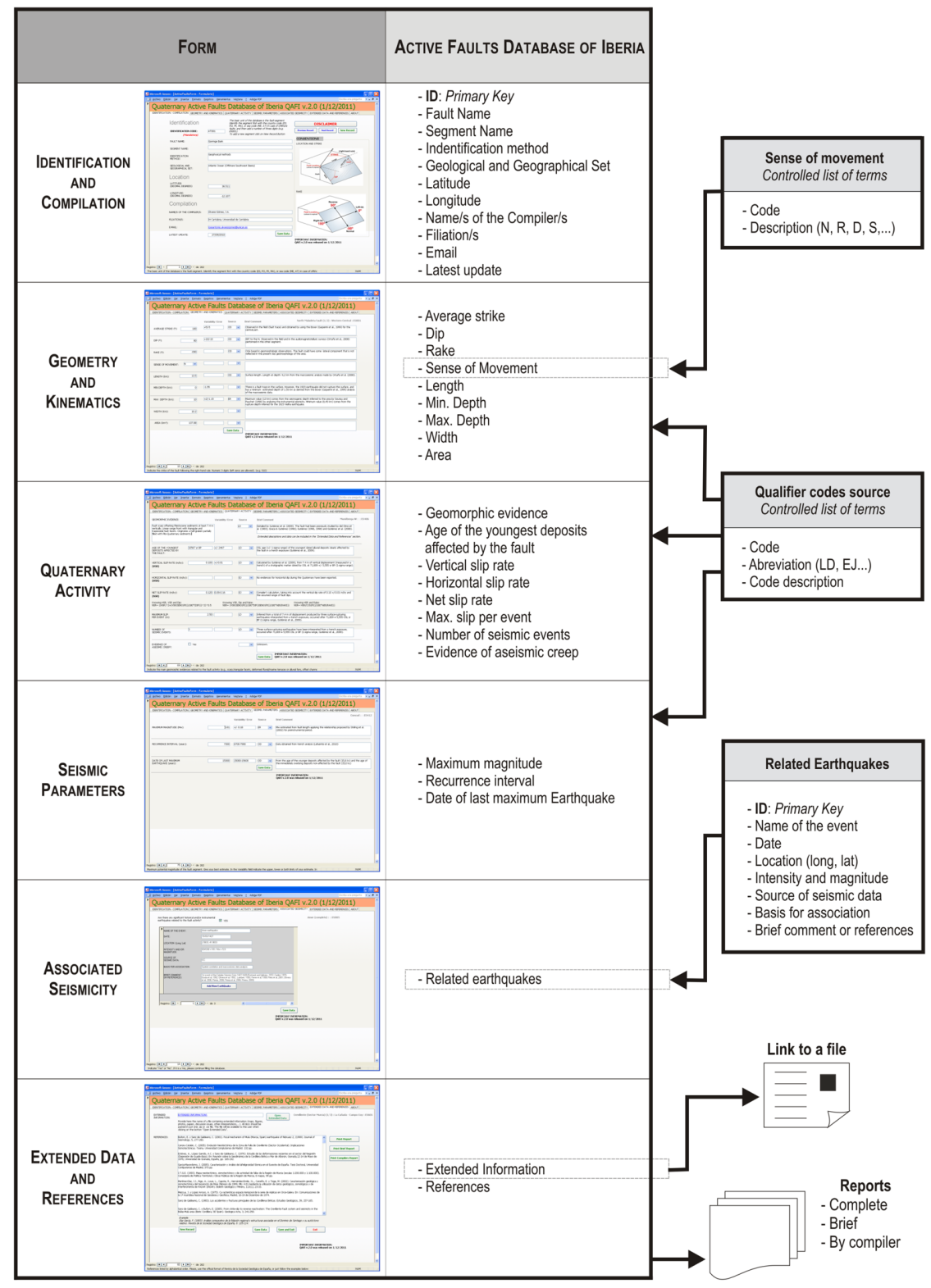

Fig. 2.- Structure of the QAFI database. Tables and associated fields are indicated with a light-grey colour headline, while dark-grey colour displays the different forms that compose the database interface in Microsoft ${ }^{\circledR}$ Access.

Fig. 2.- Estructura de la base de datos QAFI. Las tablas y sus campos asociados están indicados con un título de fondo gris claro, mientras que el color gris oscuro muestra los diferentes formularios que componen el interface de la base de

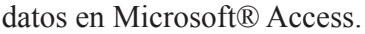

in the common Access format of the other versions, but also for the first time it can also be accessed online at: www.igme.es/infoigme/aplicaciones/QAFI/

\section{Structure of QAFI v.2.0}

The basic unit of the database (a record) is a fault, or each of the individual segments that composes a major fault. The concept of fault-segment is hereby understood in a wide sense: sections of the fault where significant changes take place. These can be major changes in geometry, in surface expression or in slip rate, which could be related to different seismic behaviour, at least in the geological short-term of Iberian geodynamics (tens of thousand years). In the database it is clearly indicated when a record represents a segment of a major fault or a single fault itself.
QAFI v.2.0 is released in two different basic formats: static, as an Access .mde file; and online through IGME web page, as an ESRI ${ }^{\circledR}$ shapefile. The structure of the database is the same in both formats, although the information is displayed differently. We shall explain the structure of the database following the Access form that shows the information, which is the same form that was used for compiling the data. This form is structured in 6 other sub-forms displaying the information illustrated in the following sections (Fig. 2):

\subsection{Identification and Compilation}

This form shows basic information on the fault and the compiler. The first field is the ID of the record, followed by the name of the fault, name of the segment, identification method, geological and geographical context, 
location coordinates, and personal information of the compiler and date of compilation. The faults are located as vector lines following the right-hand rule (Aki and Richards, 1980). Two figures illustrate the adopted conventions on fault location and sense of movement (see Fig. 2).

\subsection{Geometry and Kinematics}

Contains data regarding the average strike, dip, rake, sense of movement, length, maximum and minimum depth, width and area of the fault. The sense of movement field is automatically filled by the form depending on rake and following the Aki convention (Aki and Richards, 1980), although the compiler can also assign a value to this field by means of a controlled list of terms including: R (Reverse), N (Normal), D (Dextral), S (Sinistral), a combination of two (DN, ND, NS, SN, SR, RS, RD, DR), ANT (Anticline) and SYN (Syncline). The wi$\mathrm{dth}$ and area of the fault are also automatically filled by a routine embedded in the form provided the basic data are available.

\subsection{Quaternary Activity}

This tab summarises the information on the Quaternary activity of the fault and its main parameters. It includes the following fields: Geomorphic evidence, age of the youngest deposits affected by the fault, vertical (VSR), horizontal (HSR) and net slip rate (NSR), maximum slip per event, number of seismic events, and whether there is evidence of aseismic creep. Three different formulae are provided to calculate the net slip rate depending on available data (HSR, VSR and dip; VSR, dip and rake or HSR and rake).

\subsection{Seismic Parameters}

This form summarises basic data of the fault for seismic hazard studies: Maximum moment magnitude, recurrence interval and date of the last maximum earthquake.

\subsection{Associated Seismicity}

This form activates when the compiler considers that there is evidence for associating seismic events to the fault activity. It contains the following fields: name of the event, date, location, intensity/magnitude, source of seismic data, basis for association and brief comment or references. This information is stored in a relational table (called "Related Earthquakes") linked to the main one by the ID code (see Fig. 2).

\subsection{Extended Data and References}

This form contains a link to a file containing extended information when available, and a complete list of references. Extended information docs are provided packed in a .rar format file. The information of the record, or any record of the database, can be printed from this tab in two formats: complete and basic. A report listing the names of the compilers and their associated records can be printed also from here.

\subsection{Uncertainties}

Data included in the different fields of the database explained above correspond to the preferred estimation of the compiler. Additionally, each field-data is associated to three additional attribute-fields:

\section{Variability/Error}

This field shows either the upper and lower limits of the data estimation or the numerical error of the data measurement.

\section{Source}

This field was literally copied from the DISS database (Basili et al., 2008). It displays a controlled list of terms including: LD (literature data), OD (original data), AR (analytical relationship), ER (empirical relationship) and EJ (expert judgment).

\section{Brief Comment}

Spare memo field (250 characters max.) showing important information about the way data was calculated, the criteria for preferring one specific estimation, uncertainties involved, bibliographic references, etc.

\section{Data overview}

QAFI v.2.0 contains 262 records corresponding to 241 single faults or fault-segments; 21 records correspond to faults embracing a number of segments (multi-segment faults) (Fig. 3). The majority of the records belong to the Betic Cordillera (\#109), followed by the Iberian Massif (\#59) -including the Portuguese Orla Algarvia (\#18) and Orla Ocidental (\#15), and Catalan Coastal Ranges (\#38). Records corresponding to multi-segment faults belong to the Iberian Massif (\#12), Catalan Coastal Ranges (\#8), and Pyrenees (\#1).

A total of 43 researchers participated in compiling the data. However seven people sign as first compilers for $70 \%$ of the data. Faults in some regions such as the Catalan Coastal Ranges, Mediterranean Sea, and Iberian 


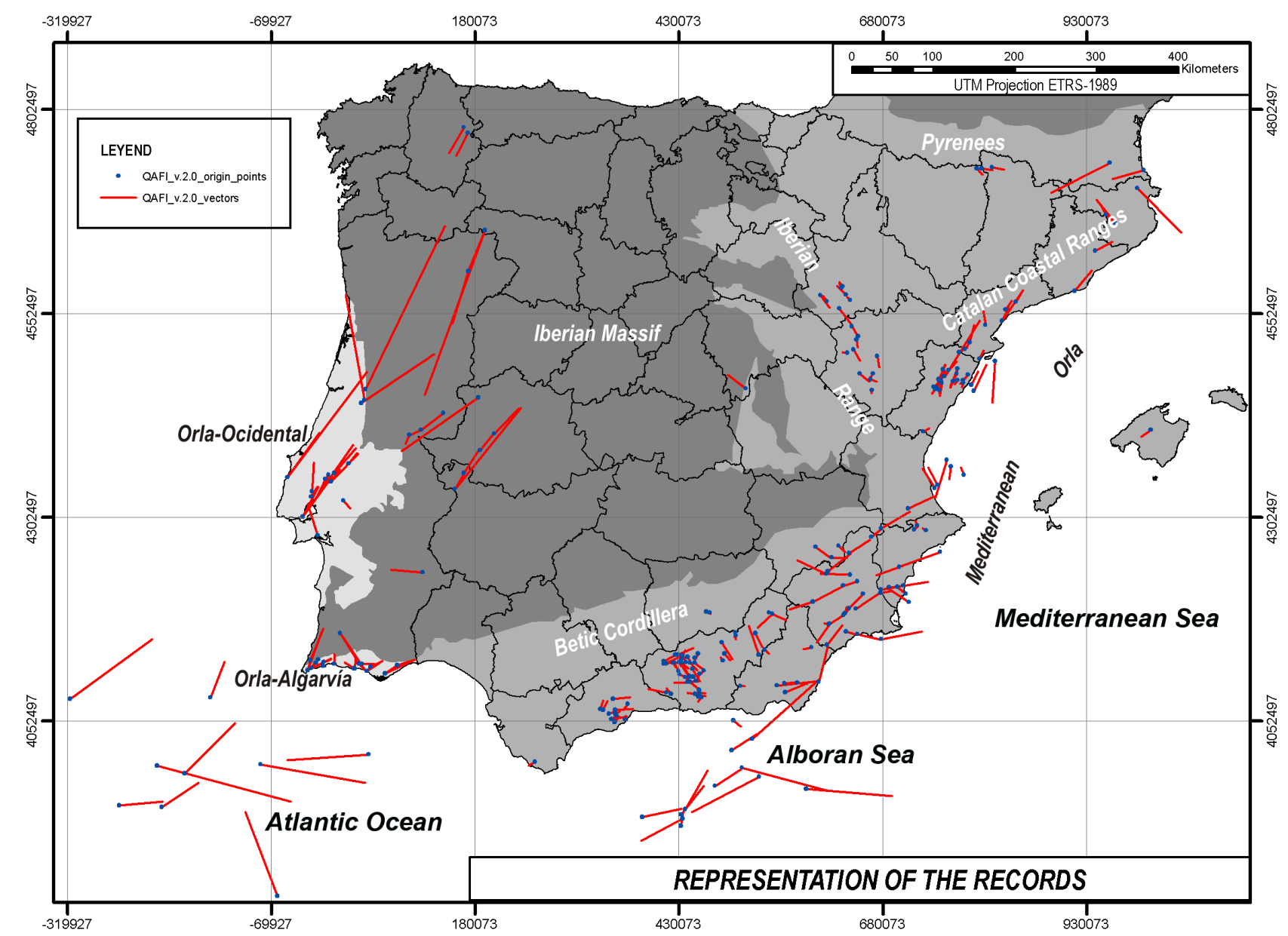

Fig. 3.- Spatial representation of the QAFI v.2.0 faults, and geological and geographical regions mentioned in text. Faults are represented as vector lines following the right-hand convention (Aki and Richards, 1980).

Fig. 3.- Representación espacial de los registros de la QAFI v.2.0. Las fallas están representadas como vectores siguiendo la regla de la mano derecha (Aki and Richards, 1980).

Range were compiled by a single primary compiler in contrast to the numerous compilers for the Betic Cordillera. A particular case are the faults located in Portuguese territory, most of them $(82 \%)$ have been adopted directly from the SHARE database (Nemser et al., 2010).

It is convenient to mention the only case of duplicity, which corresponds to the records ES681 (Ventas de Zafarraya Fault) and ES673 (Norte de Sierra Tejeda Fault). These are basically the same fault, having a very similar spatial representation, but the different interpretations by the two sets of compilers are significant enough to keep both records. The database is open to different interpretations of the same fault when these are sufficiently argued.

\subsection{Geometry and kinematics}

Fault geometry data are essential for estimating the seismogenic potential of a fault. Likewise, knowing the sense of movement of the fault is also important for mod- elling the strong ground motion from an earthquake associated to the fault. Hence, these data have been carefully reviewed in successive versions of the database with feedback from the compilers themselves.

\section{Length}

$70 \%$ of the records in the database are faults or segments less than $30 \mathrm{~km}$ long, and just 5\% are longer than $100 \mathrm{~km}$ (Fig. 4a). The most frequent (26\%) length interval is $(5-10] \mathrm{km}$ (for the sake of simplicity hereafter intervals will be written without brackets) while 50 -percentile is in the interval $10-15 \mathrm{~km}$.

The source of length data reported by the compilers is mainly from literature (LD) or original observation (OD), which in most of the cases can be both taken as the same source because the bulk of the compilers are also authors of scientific papers on the fault. Approximately $2 / 3$ of the records address the error in length measurement, 30\% of them reporting errors $\geq 5 \mathrm{~km}$. This is usually the case 
of fault-zones still poorly studied, where the cartography of the fault differs a good deal depending on scale (e.g., Palomares, Jumilla and Corredor de las Alpujarras faults). A major issue in these shear zones is that a single master fault is not identified -but a wide corridor formed by many faults of very different lengths, making it difficult to assess confidently the seismogenic potential of the fault (cf. García-Mayordomo, 2005).

The distribution of length by geological region (Fig. 5) shows that the records from the Betic Cordillera, Catalan Coastal Ranges and Iberian Range control the general shape of the distribution of lengths less than $25 \mathrm{~km}$. In these regions frequency peaks are in the 5-10, 15-20 to $20-25 \mathrm{~km}$ intervals and longer lengths occur less frequently. Faults longer than $50 \mathrm{~km}$ are located preferentially offshore in the Atlantic Ocean (Gulf of Cádiz and SW San Vicente Cape areas) and in the Mediterranean and Alborán seas. Important exceptions are records from the Iberian Massif and the Portuguese Orlas, where the longest faults of the database are reported (e.g., Penacova-Régua-Verín Fault $(222 \mathrm{~km})$ and Manteigas-VilariçaBragança $(215 \mathrm{~km}))$.

\section{Sense of movement}

The most common style of faulting reported in the database corresponds to pure normal $(47 \%)$ followed by strike-slip (39\%), while pure reverse faulting only accounts for $14 \%$ of the records. When the records are classified by geological region (Fig. 6), reverse faulting is the most common one in the Atlantic Ocean (78\%) followed by Iberian Massif (27\%) and Betic Range (11\%). Betic Cordillera is the region to encompass more variety of types of faulting with $43 \%, 11 \%$ and $46 \%$ records with pure normal, pure reverse and strike-slip movement, respectively.

Pure normal kinematics is the only type reported for the faults in the Catalan Coastal Ranges, Iberian Range, and Pyrenees. In the Iberian Massif the small fraction of pure normal faulting (5\%), or strike-slip faulting with normal component $(10 \%)$, is due to faults located in the OrlaAlgarvia Portuguese zone and in the Madrid Basin (e.g., Escopete Fault).

The three marine regions differentiated here show remarkable differences in their predominant kinematics: pure normal for the Mediterranean faults, strike-slip for the Alboran Sea ones and pure reverse for faults in the Atlantic Ocean.

\section{Depth}

In QAFI depth is input either as a minimum and maximum value. The former accounts for the distance from the ground surface to the fault plane, being $0 \mathrm{~km}$ when
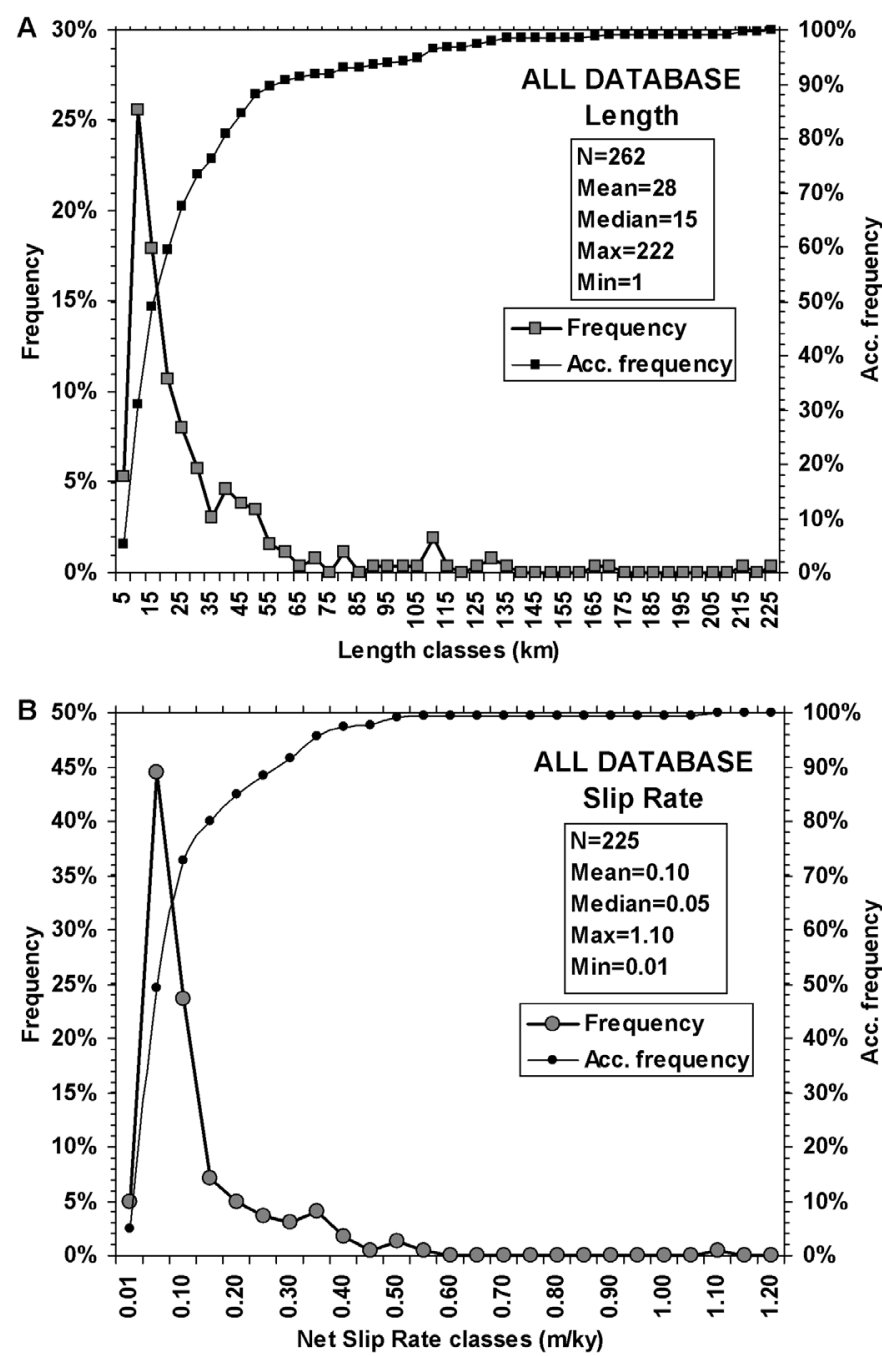

Fig. 4.- Distribution of length (a) and slip rate (b) for all the database records.

Fig. 4.- Distribución de la longitud (a) y tasa de deslizamiento (b) para todos los registros de la base de datos.

the fault cuts through the surface. For $45 \%$ of the records this value is not zero (blind faults), and of these, $9 \%$ account for depths between $0.5-1.5 \mathrm{~km}$. Most of these records (86\%) are faults located in the Portuguese Iberian Massif and Orlas, Catalan Coastal Ranges, and Mediterranean. It is interesting to note that error reported for this parameter is of a similar order $( \pm 1 \mathrm{~km})$.

The maximum depth field is filled in $85 \%$ of the records; however, it is worth mentioning that in previous versions of the database the percentage was much smaller. It is commonly difficult for the compiler to define a maximum depth because it can vary significantly depending on the considered criteria. Some compilers reported minimum depths as detected by shallow geophysical prospection (few $\mathrm{km}$ ), while others reported values corresponding to lower crustal levels or even the lithosphere (few tens of $\mathrm{km}$ ). Maximum depth of the fault in QAFI 
v.2.0 corresponds ideally to the maximum depth where fragile deformation can still go on in the fault plane and so earthquakes can be produced -i.e., the depth of the seismogenic crust. In QAFI v.2.0 maximum depth is now primarily reported based on the rheology of the crust or the focal distribution of seismicity.

The average maximum depth reported in the database is $15 \mathrm{~km}$. Only $24 \%$ of the faults are deeper than $15 \mathrm{~km}$, and belong to the Iberian Massif and the Atlantic regions, with averages of 20 and $47 \mathrm{~km}$, respectively. In the Betic Cordillera different average values can be drawn for faults located in the Eastern to the Western Betics, the former being deeper $(8-15 \mathrm{~km})$ than the latter $(5-10 \mathrm{~km})$. Only $54 \%$ of the records report an error estimate, which is commonly larger than $5 \mathrm{~km}$.

\subsection{Quaternary activity}

Quaternary activity data represents evidently the main core of the database. They are fundamental for classifying the activity of the fault as so for seismic hazard applications.

\section{Geomorphic evidence}

This is an alphanumeric memo-field devoted to summarising the geological evidence of recent activity of the fault. $77 \%$ of the records have information in this field that include mountain front scarps, triangular facets, geomorphic indices, tilting of geomorphic surfaces (terraces, alluvial fans), offsetting of canals and controls on drainage network. Obviously, direct evidence, as faulting or deforming of Quaternary deposits, are also cited. Most of the records that do not show information in this field $(23 \%)$ are either Portuguese faults - because this information was not available from the SHARE database at the time they were included in QAFI v.2.0, or offshore faults.

\section{Age of the youngest deposits affected by the fault}

This field is completed in $58 \%$ of the records. It is given generally in relative terms referring to different stages of the Quaternary period (e.g., Holocene, Upper Pleistocene,...). Only $20 \%$ of the records report the age in absolute terms.

\section{Slip Rate}

Fault slip rates are probably the most important data regarding the recent activity of a fault. At the different stages of the database evolution compilers were prompted to fill in this field even when they had to do it based on their expertise. However, in QAFI v.2.0 $14 \%$ of the records still lack this information; half of them (48\%) belonging to marine regions as the Alboran Sea or the
Atlantic OceThe distribution of slip rate (Fig. 4b) shows a clear peak at the interval $0.01-0.05 \mathrm{~m} / \mathrm{ky}$ above which it decays with subtle peaks at $0.30-0.35$ and $0.45-0.50 \mathrm{~m} /$ ky. Likewise with length, the general shape of the whole dataset distribution is due to the contribution of records from Betic Cordillera, Catalan Coastal Ranges and Iberian Range (Fig. 7). Offshore Alboran and Mediterranean regions also have a similar distribution of slip rate, with a marked peak at the 0.01-0.05 m/ky interval. Regarding the Atlantic Ocean region, only one record has a reported slip rate (e.g., Horseshoe fault). The Iberian Massif slip rate distribution also shows a conspicuous peak at 0.01$0.05 \mathrm{~m} / \mathrm{ky}$ but it stands out from other regions because the frequency decay is much smoother and shows a significative fraction of records with slip rates in between $0.15-0.30 \mathrm{~m} / \mathrm{ky}$. Most of these records $(71 \%)$ are in the Portuguese Orla-Ocidental zone.

The Betic Cordillera shows the larger average slip rate $(0.16 \mathrm{~m} / \mathrm{ky})$, followed by the Iberian Massif and Portuguese Orlas $(0.09 \mathrm{~m} / \mathrm{ky})$, and the Iberian Range $(0.07 \mathrm{~m} /$ ky) (see Fig. 7). The largest slip rates in the database are reported for the Carboneras ( $1.10 \mathrm{~m} / \mathrm{ky})$, Alhama de Murcia $(0.50 \mathrm{~m} / \mathrm{ky})$ and Carrascoy faults $(0.54 \mathrm{~m} / \mathrm{ky})$.

Slip rate is given mostly for the vertical component $(72 \%)$; very few records give the horizontal component $(6 \%)$. Practically all of the vertical slip rate estimations $(95 \%)$ indicate the source of the data, this being fundamentally "Literature data" (LD) (51\%) followed by "Original Data" (OD) (28\%) and "Expert Judgment (EJ) $(20 \%)$. When the net slip rate field is filled, source is addressed very differently: $14 \%, 5 \%$ and $76 \%$, respectively. The vertical slip rate "variability/error" field is filled in $66 \%$ of the cases and is given fundamentally as a range of upper and lower limits. Based on this information the average error has been here estimated in $\pm 0.04 \mathrm{~m} /$ $\mathrm{ky}$, although in certain cases it can be as large as $\pm 0.4 \mathrm{~m} /$ ky. Regarding the net slip rate, only $39 \%$ of the records indicate information on the uncertainty, being the average error $\pm 0.05 \mathrm{~m} / \mathrm{ky}$. These are very significant errors as the average and median slip rate of the database - either vertical or net, is 0.10 and $0.05 \mathrm{~m} / \mathrm{ky}$, respectively.

In general slip rates are calculated assuming temporal windows of few m.y. The use of the term Plio-Quaternary for considering ages ranging 5 to $2 \mathrm{Ma}$ is very common in Betic Cordillera, Catalan Coastal Ranges, Mediterranean, Pyrenees and Iberian Range. The Betic Cordillera shows the major diversity in ages considered to calculate slip rates: 50\% encompass few m.y. (from 1 to 10 m.y.), 26\% are Quaternary slip rates (e.g., Late Pleistocene-last 125 ka, Middle Pleistocene-125-780 ka); it is also interesting to note that in $18 \%$ of the records slip rates were assigned by comparison to other similar or nearby faults. 

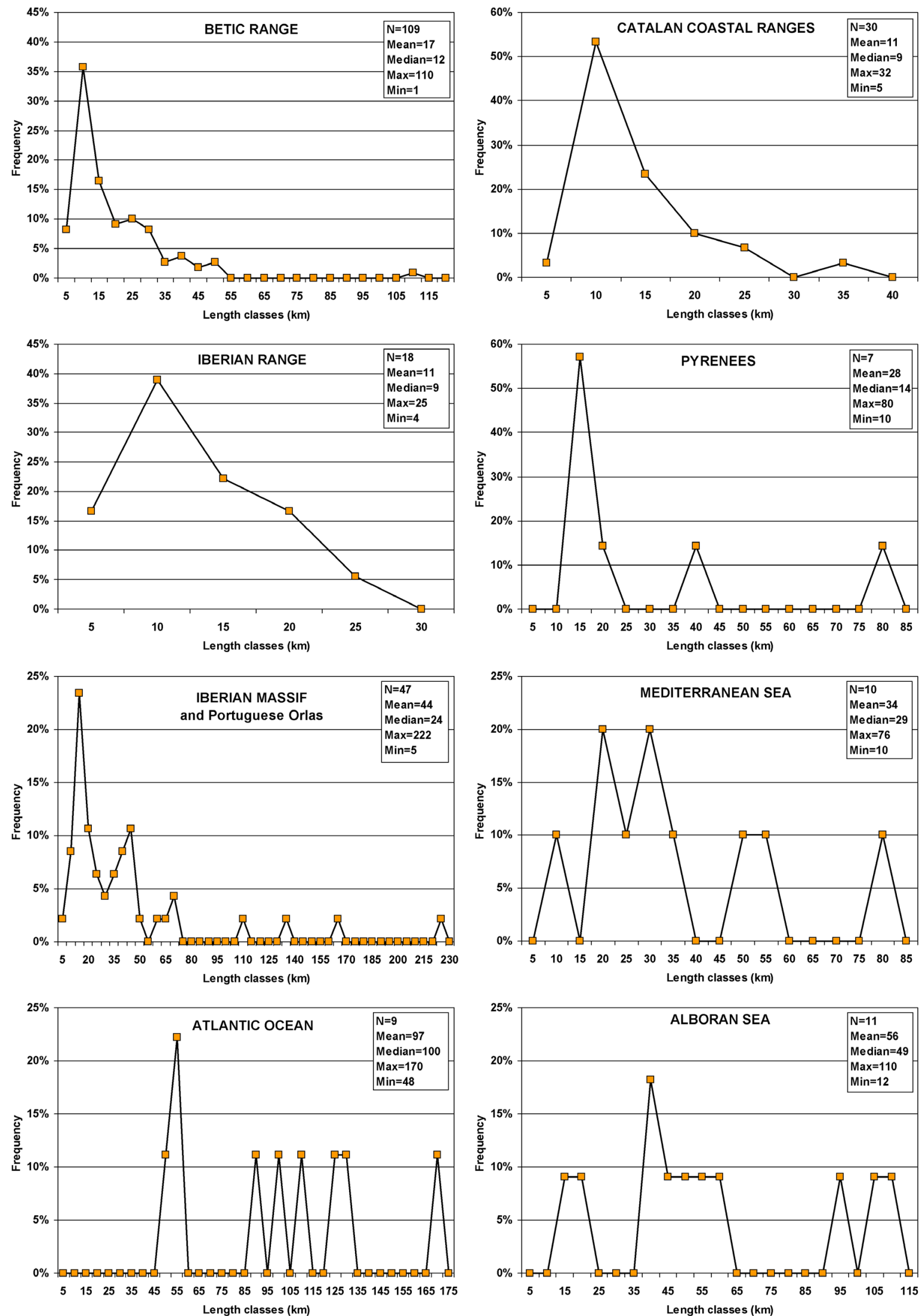

Fig. 5.- Distribution of length by geological region (see Fig. 3). Only records corresponding to single faults, or individual segments, are considered in Catalan Coastal Ranges, Pyrenees and Iberian Massif regions.

Fig. 5.- Distribución de la longitud por regiones geológicas (ver Fig. 3). En las Costero Catalanas, Pirineos y Macizo Ibérico se consideran sólo los registros correspondientes a fallas singulares o segmentos individuales. 


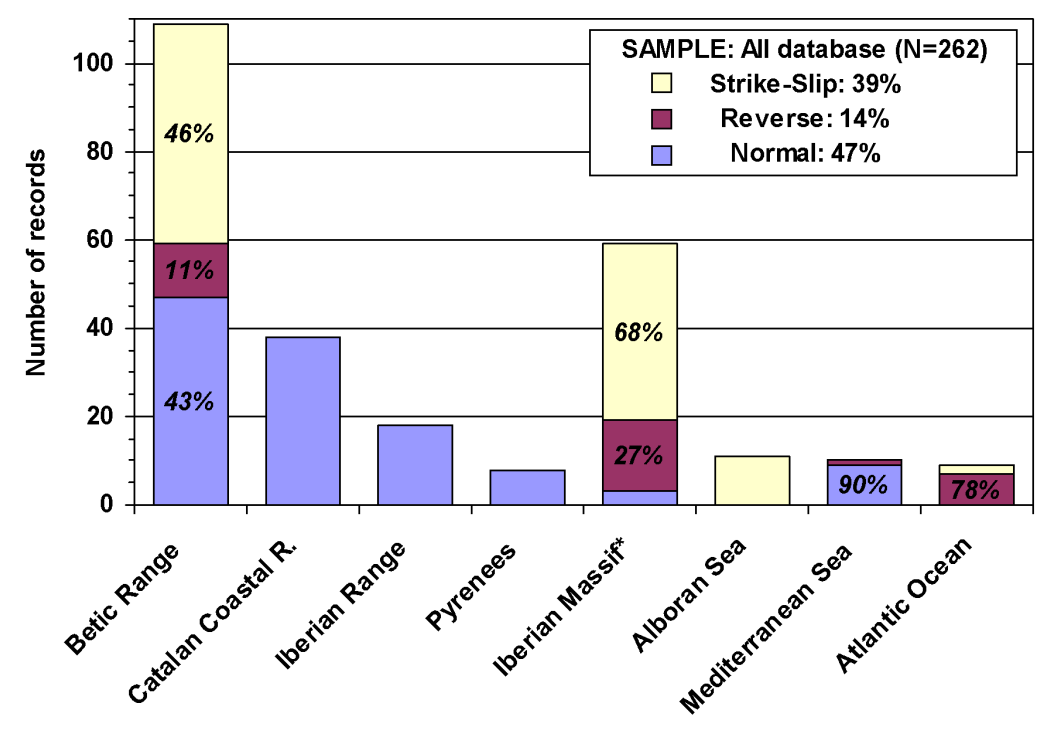

Fig. 6.- Fault kinematics by geological region for all the records in the database. Figures indicate relative frequencies of each faulting type in the specific region when convenient.

Fig. 6.- Cinemática de las fallas por región geológica para todos los registros de la base de datos. Los números indican las frecuencias relativas de cada tipo de mecanismo en las regiones correspondientes cuando es necesario.

\section{Maximum slip per event}

This field is completed in 10\% of the records. Approximately in half of them it corresponds to empirical estimations using Wells and Coppersmith (1994) regression of surface rupture length on maximum displacement; there are also estimations based on data of similar faults. In the rest of the records the estimation is based on paleoseismological work. Data ranges from 0.22 to $2.5 \mathrm{~m}$ with an average and median of 1.03 and $0.77 \mathrm{~m}$, respectively. There is a clear outlier of $6.4 \mathrm{~m}$ from the Benasau Fault (ES624) in the Betic Cordillera.

\section{Number of seismic events}

Only $8 \%$ of the records have this field completed. Approximately half of them are estimations inferred from the occurrence of historical earthquakes that the compiler attributes to the fault. The rest of the records report data based on specific paleoseismological studies (Table 1). In overall, the number of seismic events reported varies from 2 to 8 in temporal periods ranging from $300 \mathrm{ka}$ to the last 7,000 years. The fault showing the higher frequency is the Ventas de Zafarraya Fault (ES681) with 3 events reported in the last 8,800 years.

\section{Evidence of aseismic creep}

Potential evidence of aseismic creep is reported only for two records in the database (ES003 and ES742).

\subsection{Seismic parameters}

\section{Maximum magnitude}

These data are given in practically all of the records (95\%), and principally making use of the Wells and Coppersmith (1994) regressions considering the length of the fault as the "surface rupture length" (SRL) variable. Compilers use commonly the equation derived for the entire sample -i.e., with no distinction on style of faulting, although a significative fraction also consider the equations for normal or reverse faulting. Compilers also considered Stirling et al. (2002) equation for preinstrumental data, but this is done basically only in the Iberian Range faults. Finally, for many Atlantic Ocean faults the relation of Scholz (2002) based on aspect ratio is also used. It is interesting to note that these latter two regression equations result in much larger magnitudes than Wells and Coppersmith (1994).

A few records $(<5 \%)$ use area instead of length or consider other equations based on other variables but length (e.g., displacement, slip rate). The "variability/error" field is only completed in $45 \%$ of the records and the great majority of them $(>80 \%)$ just provide the standard deviation of the equation used rather than estimations derived from the uncertainty in the independent variable (length, area).

\section{Recurrence}

Forty-five percent of the records that provide data on maximum magnitude also provide its recurrence. Most of them (72\%) estimate the recurrence from Wesnousky's approach (Wesnousky 1986), and in other cases combining this with Villamor and Berryman (1999) regression of slip rate on recurrence or the Slemmons chart (1982). A small fraction (10\%) give recurrence in relative terms, like "longer than 10,000 years" or "much longer than 10,000 years", based on the age of the last deformations attributed to the fault. Finally, the few faults having paleoseismological studies (Table 1), show recurrences based on dating events in trenches.

The "variability/error" field is filled in $90 \%$ of the cases. Generally this is estimated based on different as- 


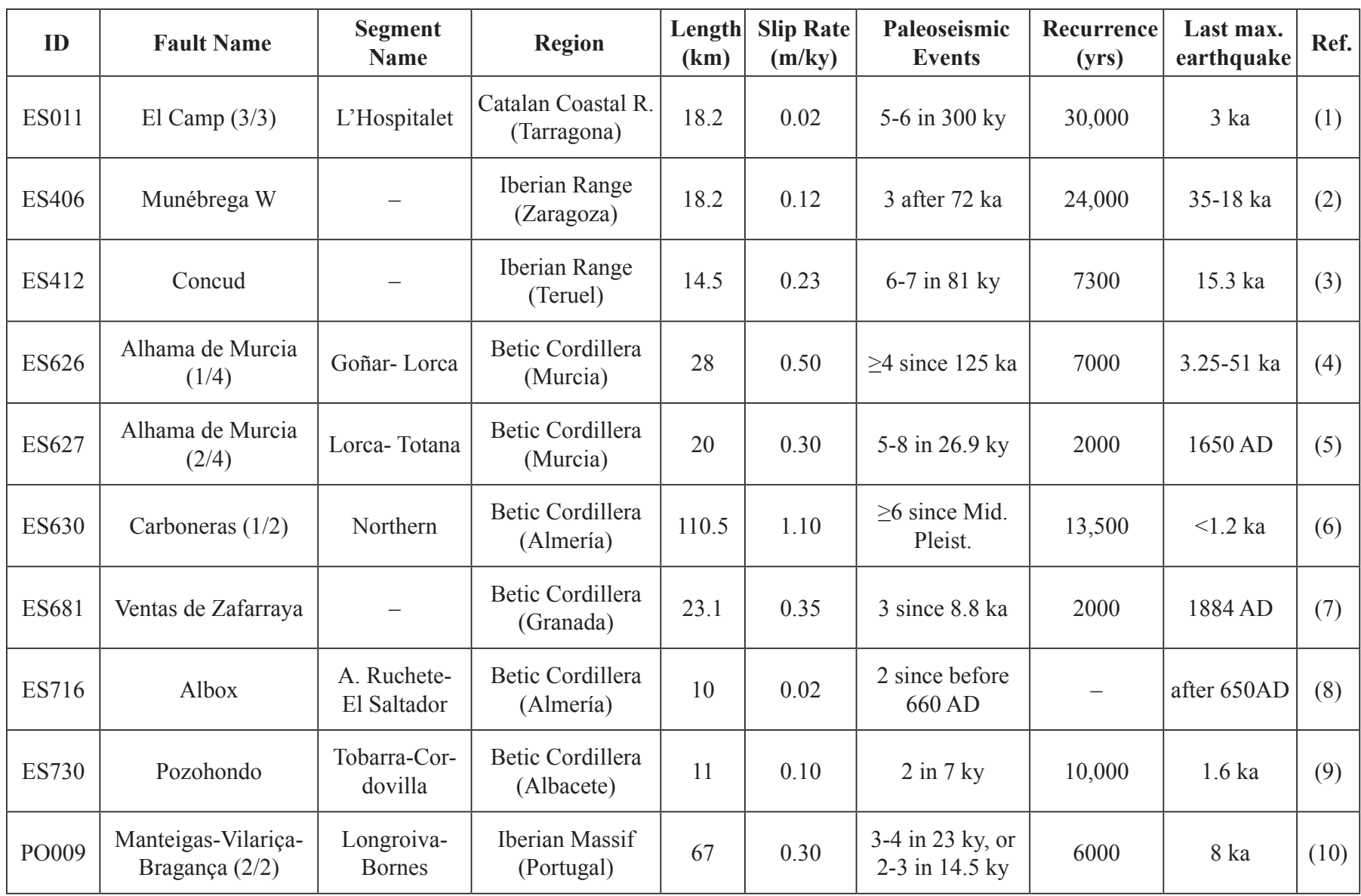

(1) Masana et al. (2001) and Santanach et al. (2010) in Perea (2010)

(2) Gutiérrez et al. (2009) in González (2010)

(3) Lafuente et al. (2010) in Lafuente et al. (2010)

(4) García-Mayordomo (2005) and Ortuño et al. (in prep.) in Martínez-Díaz et al. (2010)

(5) Masana et al. (2004) and García-Mayordomo (2005) in Martínez-Díaz et al. (2010)

Table 1.- Faults included in the QAFI v.2.0 database that have data from paleoseismic investigations. Their main characteristics and paleoseismic results are summarised. Refer to the database and references therein for more information. ky: thousand years, ka: thousands years ago. AD: calendar year.

Tabla 1.- Fallas incluidas en la QAFI v.2.0 que contienen información de trabajos específicos de paleosismicidad. Se resumen sus principales características y resultados paleosísmicos. Para más información acudir a la base de datos y a las referencias en ella incluidas. ky: mil años, ka: miles de años atrás. AD: año del calendario.

sumptions on slip rate, number of events in trenches, dating errors, or because of considering different analytical/ empirical approaches.

\section{Date of the last maximum event}

Twelve percent of the records that both give maximum magnitude and recurrence also provide an estimate of the date of the last event. This date is either given based on paleoseismicity studies (knowing the date of the youngest deposits not affected by the fault) or based on the date of historical earthquakes associated by the compiler to the fault.
(6) Moreno et al. (2008) in Moreno et al. (2010)

(7) Reicherter et al. (2003) in Rodríguez-Peces and García-Mayordomo (2010)

(8) Masana et al. (2005) in García-Meléndez (2010)

(9) Rodríguez-Pascua et al. $(2008,2009)$ in Pérez-López et al. (2010)

(10) Rockwell et al. (2009) in Cabral (2011) 

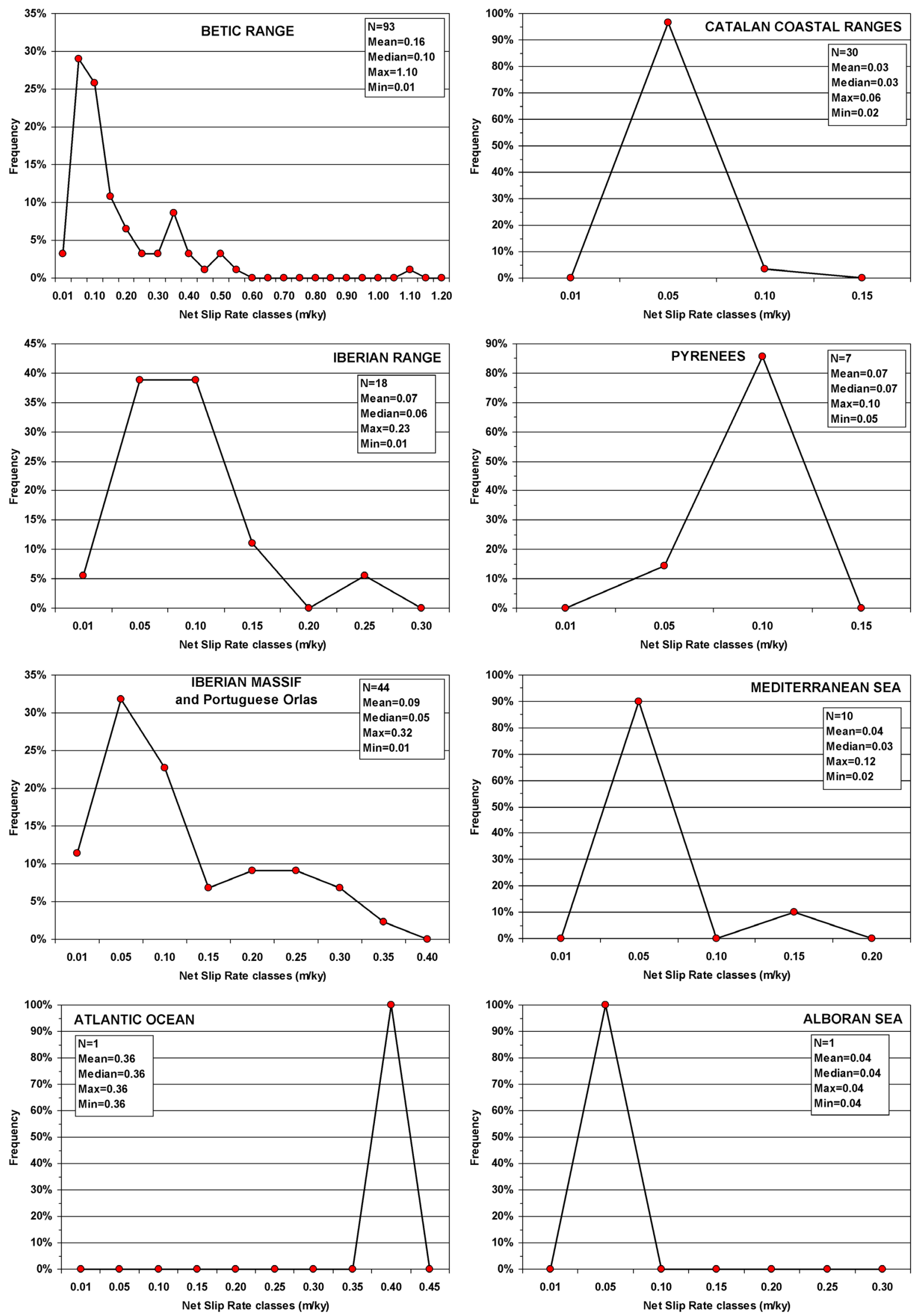

Fig. 7.- Distribution of slip rate by geological region (see Fig. 3). Only records corresponding to single faults, or individual segments, are considered in Catalan Coastal Ranges, Pyrenees and Iberian Massif regions.

Fig. 7.- Distribución de la tasa de deslizamiento por regiones geológicas (ver Fig. 3). En la Cadena Costero Catalanas, Pirineos y Macizo Ibérico se consideran sólo los registros correspondientes a fallas singulares o segmentos individuales. 


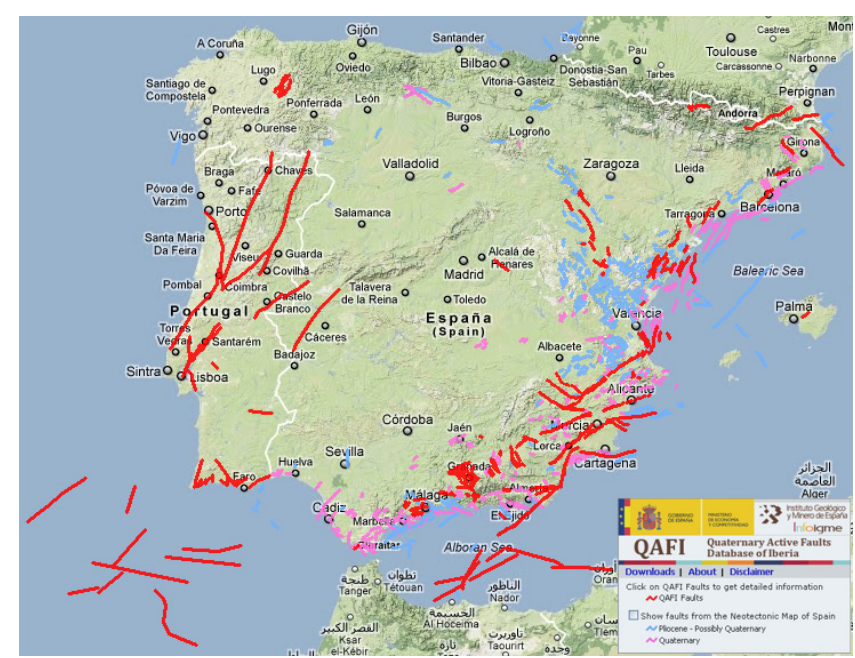

Fig. 8.- Plot combining QAFI faults and faults from the Neotectonic Map of Spain (IGME and ENRESA, 1998). The figure is screendump modified from the QAFI v.2.0 online version (www.igme.es/ infoigme/aplicaciones/QAFI/). Background is from Google Maps.

Fig. 8.- Representación combinando las fallas de la QAFI y del Mapa Neotectónico de España (IGME and ENRESA, 1998). La figura es un volcado de pantalla modificado de la versión online de QAFI v.2.0 (www.igme.es/infoigme/aplicaciones/QAFI/). El mapa de fondo es de Google Maps.

earthquakes in total, fundamentally from the historical period (pre-1920). Most of the associations take place in the Betic Cordillera and with well known historical earthquakes (e.g., 1884 Arenas del Rey, 1829 Torrevieja, 1531 Baza) but also in the Catalan Pyrenees (e.g., 1373 Ribagorça, 1427 Amer, 1923 Vielha), Iberian Range (e.g., 1917 Daroca, 1927 Alfambra, 1953 Used), Mallorca (e.g., 1851 Santa Eugenia, 1921 Sencelles) and to a lesser extend in the Iberian Massif (e.g., 1995 Sarriá, 2007 Escopete).

The most common (78\%) basis for association cited by the compilers is spatial proximity, obviously this takes place fundamentally with the historical records; $16 \%$ cited relationships between tectonic structure, depth and focal mechanisms. Seven percent did not fill the field.

\subsection{Extended data}

A significative fraction of the records (45\%) have associated a file with extended information. This type of information are generally papers in proceedings (most of them from the Iberfault meeting), but also posters presented in that and other meetings, thesis, etc. This information is particularly valuable as most of it is not easy to find through the internet. Other documents are articles in free-distribution journals (Geogaceta, Boletín Geológico y Minero, Cuaternario y Geomorfología, etc.). The database stores 50 documents in total.

\section{Discussion}

\subsection{Completeness}

Even though QAFI v.2.0 represents to date the most complete database of Iberian Quaternary faults, it is clear that many still remain to be compiled. To illustrate this statement, figure 8 shows a combined representation of QAFI faults and other Quaternary faults from the Neotectonic Map of Spain (IGME and ENRESA, 1998). Figure 8 also represents faults classified as Pliocene in that map, as a fraction of them may be Plio-Quaternary in the old sense -i.e., before the new Quaternary limit established at $2.59 \mathrm{Ma}$. The regions of Western Betics and the Mediterranean orla clearly show many Quaternary faults not yet catalogued in the database. Furthermore, it is also clear that there are large areas where Quaternary active tectonics are still poorly understood, as the Pyrenees and their western extension through the Cantabrian Mountains. Additionally, many "Pliocene" classified faults located in the Iberian Range, which share geomorphic features with known Quaternary faults, might be Quaternary when studied in detail.

Notably, $20 \%$ of the records in the database do not describe any Quaternary evidence of activity, geomorphic evidence nor report any data on the age of the youngest deposits affected by the fault. Most of these records $(80 \%)$ are Portuguese faults and their information was taken straightforward from a preliminary version of the SHARE database (Nemser et al., 2010), where this information was not available at that time. Nevertheless, the Portuguese faults will be revised and completed by staff from the Portuguese Geological Survey (LNEG) in collaboration with IGME, with a view to updating the database in the near future. The rest of the records are 8 major faults located in the Atlantic Ocean and Alboran Sea regions, all of them compiled by the same individual; and 1 fault in the Betic Cordillera (Botardo-Alfahuara Fault) whose Quaternary activity is under question.

Another interesting issue is that even though a significative fraction of the faults in the database (39\%) are described as strike-slip faults -either pure or with vertical component, horizontal slip rates are seldom reported. This highlights the difficulty in assessing horizontal movements in Iberian faults, due to their slow slip rates, an also that geologists should put more effort in trying to evaluate it. Likewise, geologists have to put more effort in assessing the variability or errors in their estimations. A significative fraction of certain important parameters lacks this valuable information (e.g., 34\% in slip rate estimations, 55\% in maximum magnitude assessments). 
Fig. 9.- Comparison among length (a) and slip rate (b) frequency distributions of Betic Cordillera, Catalan Coastal Ranges and Iberian Range records.

Fig. 9.- Comparación entre la distribución de frecuencias de la longitud (a) y la tasa de deslizamiento (b) en la Cordillera Bética, Cadenas Costero Catalanas y Cadena Ibérica.
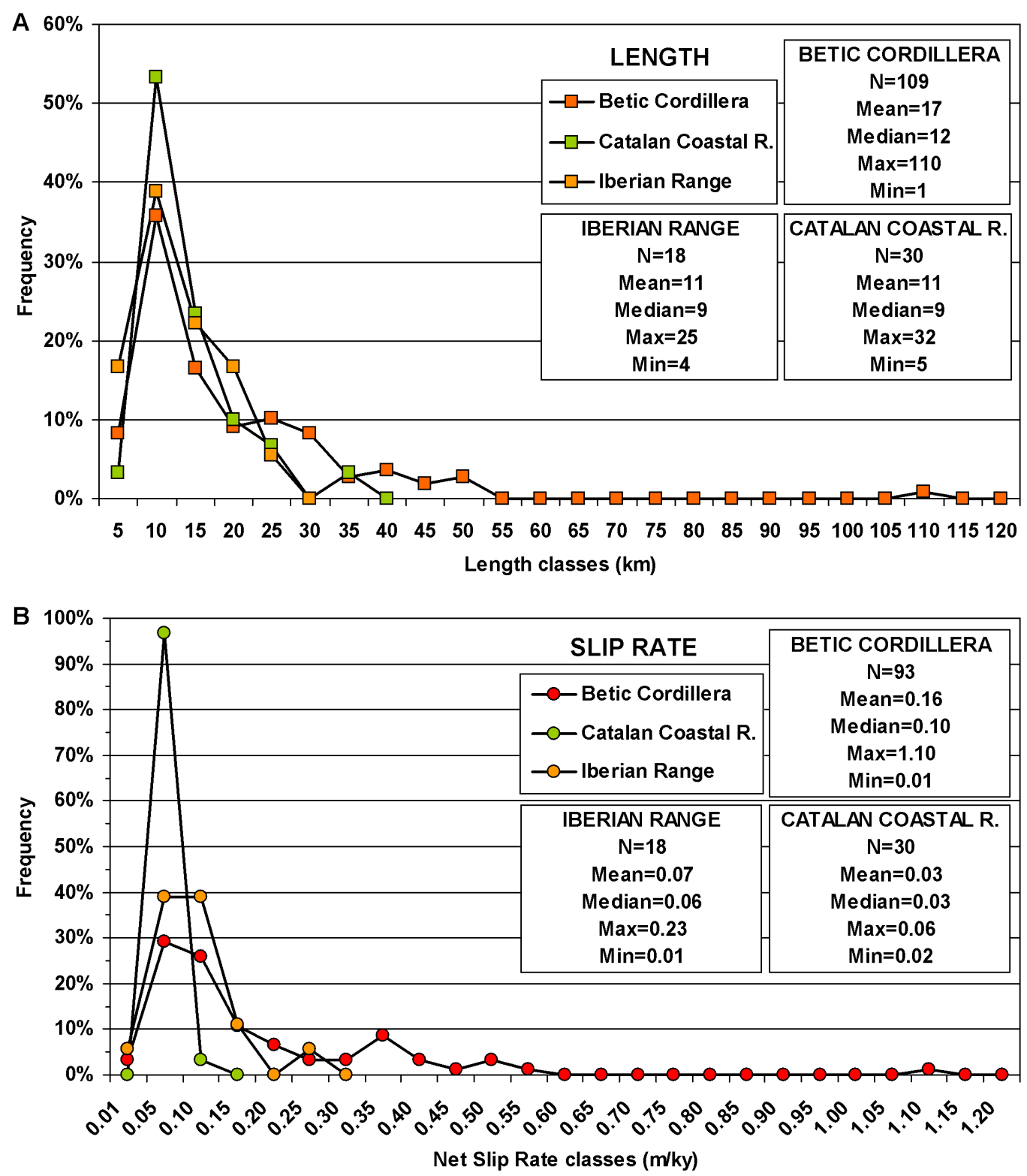

Hence, it is clear that new versions of the database will include many more faults and further revisions of existing records.

\subsection{Uniformity}

Another important issue is the fact that records from some regions are mostly compiled by the same individual. This the case of the Iberian Range, Catalan Coastal Ranges, and Iberian Massif (Portugal) faults. This implies that information on those regions should be more uniform than in others (compiler effect), as it is expected that the compiler uses the same criteria for evaluating Quaternary activity and similar assumptions for estimating parameters. This should be particularly clear when comparing parameters that require expertise criteria -like depth of the fault, slip rates, and seismic parameters, from one region to another. For example, the latter is very obvious when comparing maximum magnitudes in the Iberian Range, where Stirling et al. (2002) pre-instrumental equation has been used, to other regions which use Wells and Coppersmith (1994).

However, if we compare the shape of the frequency distribution of length and slip rate of the Catalan Coastal Ranges and Iberian Range to the Betic Cordillera (Fig. 9) -which is the one having a major diversity of compilers, it shows that they are all similar, and that average slip rates increase from the Catalan Coastal Ranges $(0.03 \mathrm{~m} /$ $\mathrm{ky})$, Iberian Range $(0.07 \mathrm{~m} / \mathrm{ky})$ to the Betic Cordillera $(0.16 \mathrm{~m} / \mathrm{ky})$, while average lengths are of a similar order (11, 11, and $17 \mathrm{~km}$, respectively). This suggests that even when the compilers of the different regions may have 

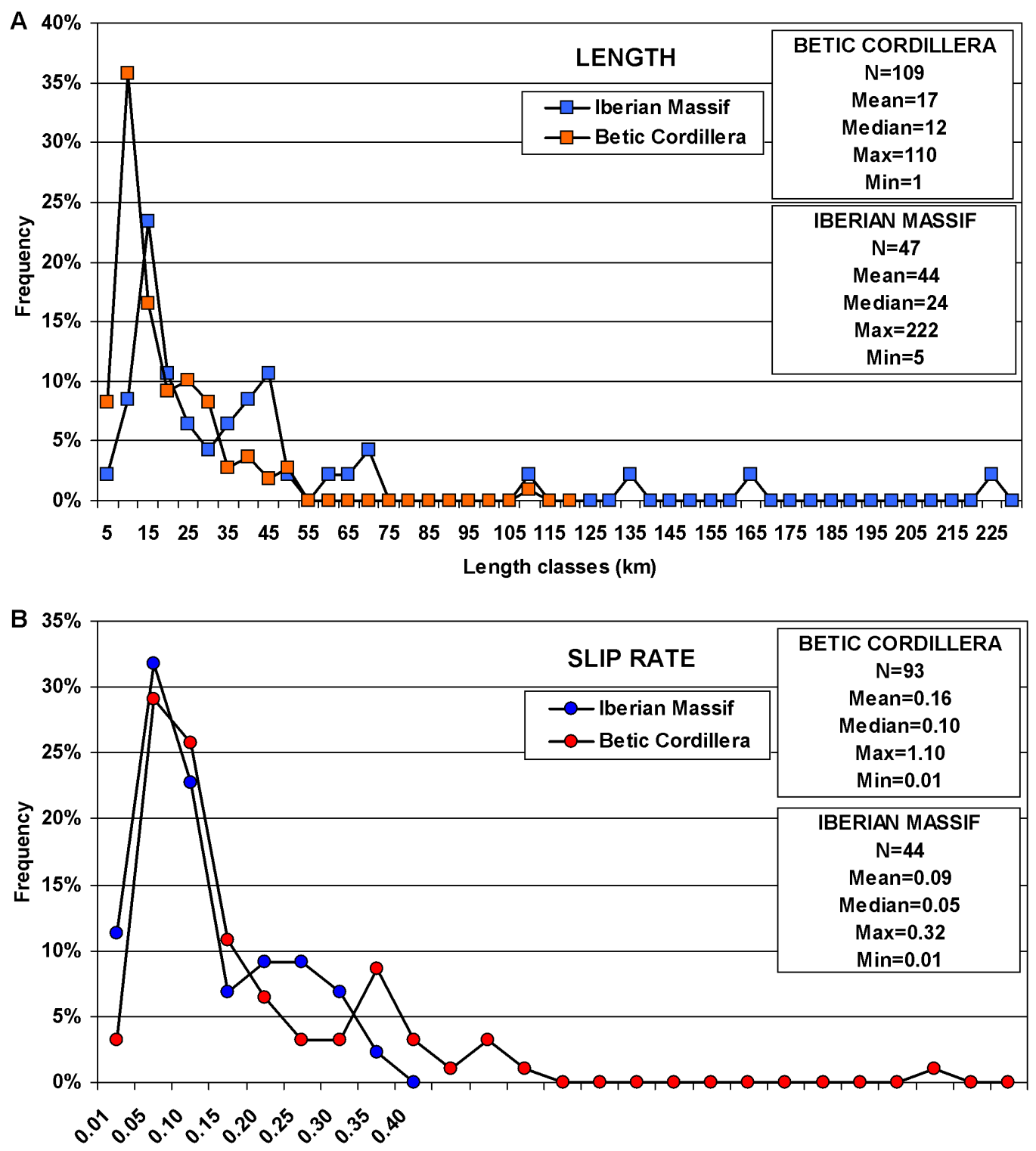

Fig. 10.- Comparison between Betic Cordillera and Iberian Massif length (a) and slip rate (b) frequency distributions.

Fig. 10.- Comparación de la distribución de frecuencias de la longitud (a) y la tasa de deslizamiento (b) entre la Cordillera Bética y el Macizo Ibérico

\section{Net Slip Rate classes (m/ky)}

considered different criteria compiling the data, the general output is comparable and reasonable with the Iberian Quaternary geodynamics.

Conversely, when slip rate and length distribution of the Iberian Massif is compared to the Betic Cordillera, major differences arise (Fig. 10). The shapes of the length distributions are rather different showing that Iberian Massif records have average lengths $(44 \mathrm{~km})$ much larger than the Betic Cordillera $(17 \mathrm{~km})$. Furthermore, the shape of the slip rate distribution in the Iberian Massif shows a particular frequency rise for slip rates in the interval 0.15 to $0.30 \mathrm{~m} / \mathrm{ky}$, and an average slip rate of $0.09 \mathrm{~m} /$ ky. From this comparison is seems that the faults of the Iberian Massif are the longest onshore in Iberia and that they are faster than expected when compared to the Catalan Coastal Ranges or Iberian Range. However this re- sult seems very likely influenced by the compiler criteria rather than particular geodynamic reasons.

\section{Conclusions}

QAFI v.2.0 is to date the most informative source for fault-related seismic hazard in Iberia; even though the database still needs to be completely reviewed for conformity to standards. Even so, QAFI could never be considered complete or definitive due to the scientific nature of the data contained in it. Hence, it is important to make a responsible use of it. QAFI will always be a project under constant revision and updating as a consequence of the advances in the knowledge about the structures capable of generating earthquakes in Iberia. 


\section{Acknowledgments}

The development of the database has been supported by projects FASEGEO (CGL2009-09726) and IBER $\neg$ FAULT (CGL2009-07388), both funded by the Spanish Ministry of Science and Innovation, and by project "Evaluación de la Peligrosidad Sís $\neg$ mica en España para Aplicaciones relacionadas con la Seguridad Nuclear (funded by Consejo de Seguridad Nuclear (CSN)). The October 2010 Iberfault meeting was also funded by the European Commission SHARE project (FP7-226967). A previous meet $\neg$ ing in January 2010 (Olhão, Portugal) was organized and funded by the Iberian Region Group of SHARE WP.3 (Instituto Superior Técnico, Portugal). The authors thank J. Fonseca and S. Vilanova (IST, Portugal), R. Basili, V. Kastelic and G. Valensise (INGV, Italy) and P. Villamor and K. Berryman (GNS, New Zealand) for their encour $\neg$ agement to carry out this initiate. The first author also acknowledges IST and SHARE for covering travelling expenses to a number of SHARE meetings. LNEG-Por $\neg$ tugal is acknowledged for agreeing collaborating jointly with IGME in keeping the database updated. During the database development A. Jiménez-Díaz enjoyed a grant funded by the CSN project and R. Martín-Banda was under a research contract funded by FASEGEO. K. Heller (USGS) and an anonymous reviewer are thanked for constructive reviews that led to an improved version of the paper. N. Woollard is acknowledged for reviewing the English.

\section{References}

AFRC (2010): Active Faults Database of Japan. Accessed Jan, 2010, from AIST web site: http://riodb02.ibase.aist.go.jp/activefault/ index_e.html

Aki, K., Richards, P.G. (1980): Quantitative Seismology: Theory and Methods. Vol. 1. W.H. Freeman and Company, 557 p.

Basili, R., Valensise, G., Vannoli, P., Burrato, P., Fracassi, U., Mariano, S., Tiberti, M.M., Boschi, E. (2008): The Database of Individual Seismogenic Sources (DISS), version 3: summarizing 20 years of research on Italy's earthquake geology. Tectonophysics. doi:10.1016/j.tecto.2007.04.014.

Cabral, J. (2010): Manteigas-Vilariça-Bragança (2/2) Fault: Longroiva-Bornes segment (PO009). In: García-Mayordomo et al. (eds.), Quaternary Active Faults Database of Iberia v.2.0 - December 2011. IGME, Madrid.

DISS Working Group (2010): Database of Individual Seismogenic Sources (DISS), Version 3.1.1: A compilation of potential sources for earthquakes larger than M 5.5 in Italy and surrounding areas. http://diss.rm.ingv.it/diss/

García-Mayordomo, J. (2005): Caracterización y Análisis de la Peligrosidad Sísmica en el Sureste de España. PhD Thesis, Complutense University, 373 pp. Available online: http://www.ucm.es/ BUCM/buscar/6256.php

García-Mayordomo, J., Insua-Arévalo, J.M., Martínez-Díaz, J.J., Jiménez-Díaz, A., Álvarez-Gómez, J.A., Pérez-López, R., Rodrígu-
ez-Pascua, M.A., Martín-González, F., Giner-Robles, J., Masana, E., Nemser, E.S., Cabral, J. (2010): Base de datos de fallas activas de Iberia (primera fase): objetivos y estructura preliminar. In: Insua-Arévalo, J.M., Martín-González, F. (eds.), Contribución de la Geología al Análisis de la Peligrosidad Sísmica. Resúmenes de la $1^{a}$ Reunión Ibérica sobre Fallas Activas y Paleosismología, 189$192 \mathrm{pp}$.

García-Meléndez, E. (2010): Albox Fault: Alto del Ruchete-El Saltador segment (ES716). In: García-Mayordomo et al. (eds.), Quaternary Active Faults Database of Iberia v.2.0 - December 2011. IGME, Madrid.

Gibbard, P.L., Head, M.J., Walker, M.J.C., The Subcommission on Quaternary Stratigraphy (2009): Formal ratification of the Quaternary System/Period and the Pleistocene Series/Epoch with a base at 2.58 Ma. Journal of Quaternary Science 25, 96-102.

GEM-Faulted Earth (2011): Global Active Faults and Seismic Source Database. www.globalquakemodel.org/hazard-global-components/ active-faults

GNS (2010): New Zealand Active Faults Database. Accessed Jan, 2010, from GNS web site: http://data.gns.cri.nz/af/

González, Á. (2010): Munébrega W Fault (ES406). In: García-Mayordomo et al. (eds.), Quaternary Active Faults Database of Iberia v.2.0 - December 2011. IGME, Madrid.

IGME (2012): Online access to the Quaternary Active Faults Database of Iberia (QAFI v.2.0). www.igme.es/infoigme/aplicaciones/QAFI/ (test version).

IGME, ENRESA (1998): Mapas Neotectónico y Sismotectónico de España a escala 1:1.000.000. Vol. I (237 pp.) and Vol. II (167 pp.). Available at www.igme.es

Lafuente, P. (2010): Concud Fault (ES412). ). In: García-Mayordomo et al. (eds.), Quaternary Active Faults Database of Iberia v.2.0 December 2011. IGME, Madrid.

Martínez-Díaz, J.J., Ortuño Candela, M., Masana, E., García-Mayordomo, J., Jiménez-Díaz, A. (2010): Alhama de Murcia de Fault (1/4): Goñar-Lorca segment (ES626). ). In: García-Mayordomo et al. (eds.), Quaternary Active Faults Database of Iberia v.2.0 - December 2011. IGME, Madrid.

Martínez-Díaz, J.J., García-Mayordomo, J., Jiménez-Díaz, A. (2010): Alhama de Murcia de Fault (2/4): Lorca-Totana segment (ES627). ). In: García-Mayordomo et al. (eds.), Quaternary Active Faults Database of Iberia v.2.0 - December 2011. IGME, Madrid.

Moreno, X., Masana, E., Gràcia, E. (2010): Carboneras Fault (1/2): Northern segment (ES630). ). In: García-Mayordomo et al. (eds.), Quaternary Active Faults Database of Iberia v.2.0 - December 2011. IGME, Madrid.

Nemser, E.S., García-Mayordomo, J., Cabral, J., Fonseca, J.F.B.D., Martínez-Díaz, J.J., Vilanova, S., The 2010 Working Group on Iberian Seismogenic Sources (2010): Compilation of parameterized seismogenic sources in iberia for the share europeanscale seismic source model. In: Insua-Arévalo, J.M., Martín-González, F. (eds.), Contribución de la Geología al Análisis de la Peligrosidad Sísmica, Sigüenza (Guadalajara, España), 201-204.

NEOPAL (2010): Base de Données Néopal (Déformations récentes et paléoséismes en France), BRGM. www.neopal.net

Perea, H. (2010): El Camp Fault: L'Hospitalet segment (ES011). In: García-Mayordomo et al. (eds.), Quaternary Active Faults Database of Iberia v.2.0 - December 2011. IGME, Madrid.

Perea, H., Masana, E., Santanach, P. (2006): A pragmatic approach to seismic parameters in a region with low seismicity: the case of eastern Iberia. Natural Hazards 39, 451-477.

Pérez-López, R., Rodríguez-Pascua, M.A., García-Mayordomo, J., Jiménez-Díaz, A. (2010): Pozohondo Fault: Tobarra-Cordovilla segment (ES730). In: García-Mayordomo et al. (eds.), Quaternary 
Active Faults Database of Iberia v.2.0 - December 2011. IGME, Madrid.

Rodríguez Peces, M.J., García-Mayordomo, J. (2010): Ventas de Zafarraya Fault (ES681). In: García-Mayordomo et al. (eds.), Quaternary Active Faults Database of Iberia v.2.0 - December 2011. IGME, MadridSanz de Galdeano, C., Peláez, J.A., López Casado, C. (2003): Seismic Potential of the Main Active Faults in the Granada Basin. Pure and Applied Geophysics 160, 1537-1556.

Sanz de Galdeano, C., Peláez, J.A., López Casado, C. (2007): Fallas activas y potencial sísmico de la cuenca de Guadix-Baza. In: Sanz de Galdeano, C., y Peláez, J.A. (eds.), La cuenca de Guadix-Baza, Estructura, tectónica activa, sismicidad, geomorfología y dataciones existentes, Granada, 283-289.

Scholz, C.H. (2002): The Mechanics of Earthquakes and Faulting. Cambridge University Press, $471 \mathrm{pp}$.

Slemmons, D.B. (1982): Determination of the design earthquake magnitudes for microzonation. In: Proceedings of the 3rd International Earthquake Microzonation Conference, Seattle, Washington: 1, 119-130.

Stirling, M., Rhoades, D., Berryman, K (2002): Comparison of Earthquake Scaling Relations Derived from Data of the Instrumental and Preinstrumental Era. Bulletin of the Seismological Society of America 92(2), 812-830.
Trifonov, V.G. (2004): Active Faults in Eurasia: general remarks. Tectonophysics 380, 123-130.

USGS (2010): Quaternary Fault and Fold database for the United States. Accessed Jan, 2010, from USGS web site: http://earthquakes.usgs.gov/regional/qfaults/

Valensise, G., Basili, R., Mucciarelli, M., Pantosti D. (eds.) (2002): Database of Potential Sources for Earthquakes Larger than M 5.5 in Europe, a compilation of data collected by partners of the EU project FAUST (2002). Accessible from http://www.ingv.it/ roma/ banche/catalogo europeo

Villamor, P., Berryman, K. (1999): La tasa de deslizamiento de una falla como aproximación de primer orden en las estimaciones de peligrosidad sísmica. ler Congreso Nacional de Ingeniería Sísmica, Murcia: I, 153-163.

Wells, D.L., Coppersmith, K.J. (1994): New empirical relationships among magnitude, rupture length, rupture width, rupture area, and surface displacement. Bulletin of the Seismological Society of America 84(4), 974-1002.

Wesnousky, S.G. (1986): Earthquakes, Quaternary faults, and seismic hazard in California. Journal of Geophysical Research 91(B12), 12587-12631. 


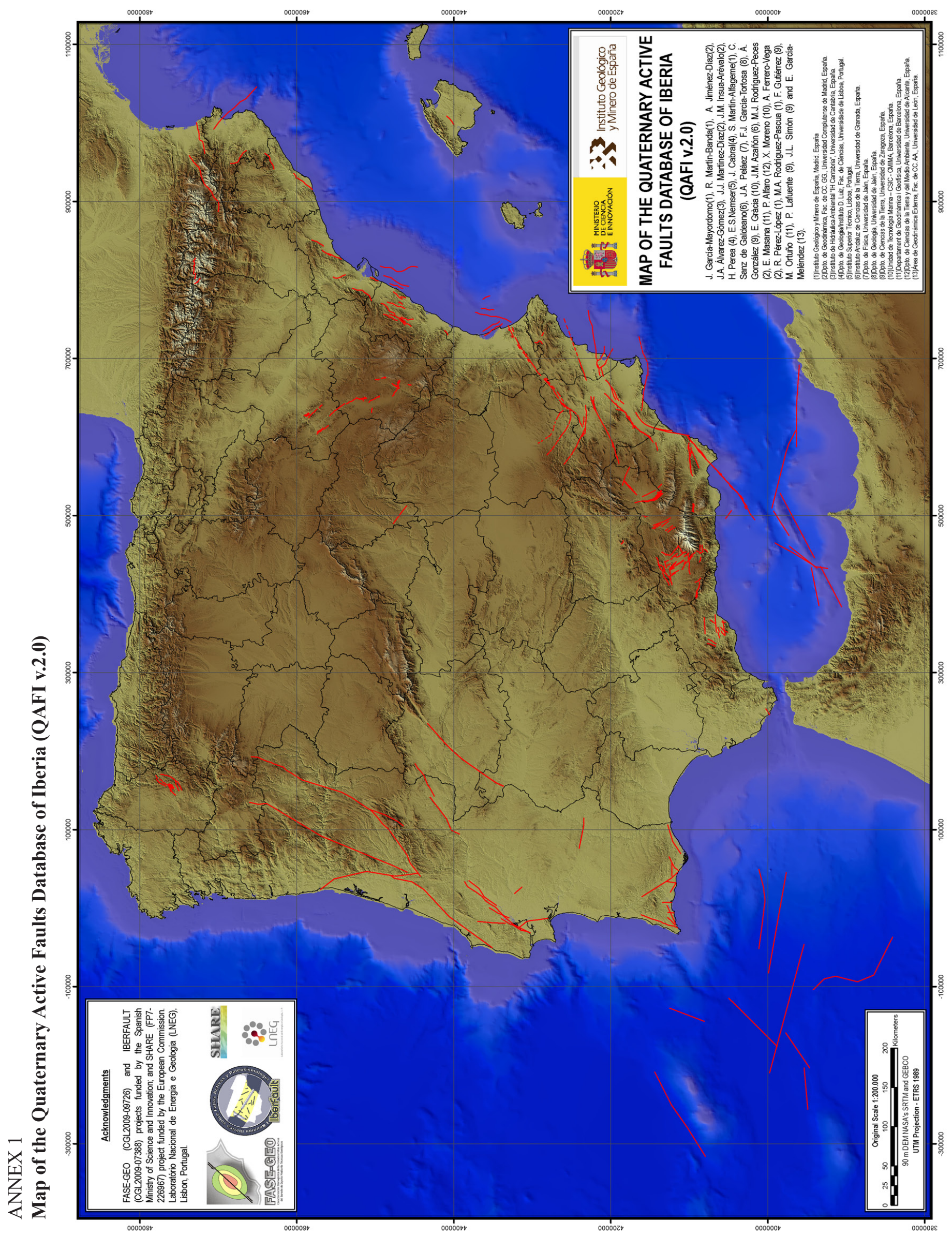

